\title{
Gold(I)/Zn(II) catalyzed tandem hydroamination/annulation reaction of 4-yne-nitriles $\dagger$
}

\author{
Ayhan S. Demir, ${ }^{* a}$ Mustafa Emrullahoğlu ${ }^{a b}$ and Kerem Buran ${ }^{a}$
}

\author{
Received 4th July 2010, Accepted 1st September 2010 \\ DOI: $10.1039 / \mathbf{c 0 c c 0 2 3 5 7 d}$
}

The tandem hydroamination-annulation reaction of 4-pentynenitriles in the presence of amine nucleophiles and a cooperatively operating catalyst system, consisting of $\mathrm{Ph}_{3} \mathrm{PAuCl}$ and $\mathrm{Zn}\left(\mathrm{ClO}_{4}\right)_{2}$, provides an efficient route to 2 -aminopyrroles. Two regioisomeric 2-aminopyrroles were formed in moderate to good yields.

Over the past six years, gold catalysis has shown to be a powerful tool in organic synthesis. Cationic gold(I) and gold(III) complexes show unique behavior towards unactivated alkenes, alkynes, allenes, 1,3-dienes, and enynes promoting the nucleophilic addition of a variety of functional groups both inter- and intramolecularly. ${ }^{1}$ In that respect, a great number of gold catalyzed tandem reactions of various systems with external nucleophiles that enable the formation of cyclic systems are present in the literature. ${ }^{2}$ Especially those transformations including the catalytic addition of $\mathrm{N}-\mathrm{H}$ bonds across $\mathrm{C}-\mathrm{C}$ multiple bonds (hydroamination) that are catalyzed by both gold(I) and gold(III) complexes have found wide application for the generation of new $\mathrm{C}-\mathrm{N}$ bonds ${ }^{3,4}$ affording nitrogen containing heterocycles, such as pyrroles and pyridines.

Among the various synthetic strategies, catalytic transformations that use transition-metal catalysts are one of the modern approaches for forming pyrroles. ${ }^{5}$ Relatively few examples of the gold-catalyzed synthesis of highly substituted pyrroles have been reported, however. ${ }^{4 e, 6}$

In the course of our research to develop new methodologies for the synthesis of nitrogen containing heterocycles that are promoted by transition metal catalysts, we recently demonstrated $\mathrm{Zn}$ (II) salts to be effective catalysts for the activation of the $\mathrm{C}=\mathrm{O}$ bond and $\mathrm{CN}$ triple bond. ${ }^{7}$ These principles led us to the discovery of a novel catalytic one-pot synthesis of 2 -aminopyrroles starting from $\alpha$-cyanomethyl- $\beta$-ketoesters. Zinc perchlorate smoothly catalyzes the amination of nitriles, and the subsequent cyclocondensation affords five-membered rings (pyrroles) in good yield, as exemplified in the conversion of 1 to 2 and 3 (Scheme 1). ${ }^{7 a}$

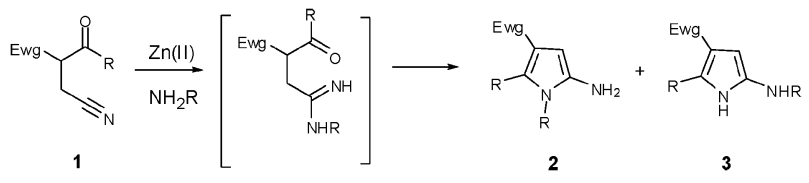

Scheme 1 Zn(II) salt catalyzed formation of pyrroles.

${ }^{a}$ Department of Chemistry, Middle East Technical University,

06531 Ankara,Turkey.E-mail: asdemir@metu.edu.tr;

Tel: 0090 (0)312 2103242

${ }^{b}$ The İzmir Institute of Technology Gülbahçe Köyü, Urla, 35430 Izmir, Turkey

$\dagger$ Electronic supplementary information (ESI) available: Tables and spectral data. See DOI: $10.1039 / \mathrm{c} 0 \mathrm{cc} 02357 \mathrm{~d}$
In light of our previous investigation wherein nitriles could be activated by $\mathrm{Zn}$ (II) salts towards nucleophilic attacks, we report herein a conceptually new synthetic approach to substituted pyrroles via a cooperative $\mathrm{Au}$ (I)/Zn(II)-catalyzed sequential inter/intramolecular hydroamination reaction of 4-yne-nitriles with various amines.

The most notable aspect of the present reaction is the sequential activation of nitriles as pronucleophiles and alkynes as electrophiles, which enables the rapid assembly of a range of 2-amino substituted pyrroles with high efficiency. 2-Aminopyrroles have been found to show interesting biological properties ${ }^{8,9}$ or have been used as precursors ${ }^{10}$ for known drugs, in which they have found use as synthetic precursors for the acyclic nucleoside analogs of the pyrrolo[2,3- $d$ ]pyrimidine ring system. ${ }^{11}$

In this simple one pot assembly, the $\alpha$-propargyl methyl nitriles (4-yne-nitriles) ${ }^{12} 4$ and a series of aliphatic and aromatic amines $\mathbf{5}$, as nucleophiles, are used as starting materials to produce pyrroles $\mathbf{6}$ and 7 with high diversity (Scheme 2).

The initial efforts focused on the optimization of an efficient system starting from 4-yne-nitrile $\mathbf{4 a}\left(\mathrm{Ewg}=\mathrm{CO}_{2} \mathrm{Et}\right)$ as a model substrate. In our initial studies, 4a was treated with aniline (5a) under various conditions (Table 1). Firstly, the inclusion of $\mathrm{Zn}\left(\mathrm{ClO}_{4}\right)_{2}$ as a potential catalyst at room temperature only led to the recovery of a starting material, in which only traces of the cyclization products 6aa and 7aa

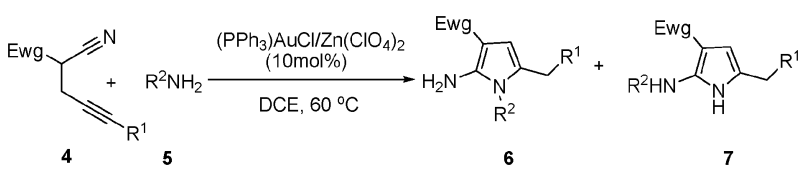

Scheme $2 \mathrm{Au}(\mathrm{I}) / \mathrm{Zn}$ (II)-catalyzed sequential inter/intramolecular hydroamination reaction of 4 -yne-nitriles with amines.

Table 1 Efficiency of the transition-metal catalysts for the transformation of $4 \mathbf{a}$ with aniline $5 \mathbf{a}$ to $6 \mathbf{a a}^{a}$ and $7 \mathbf{a a}^{a}$

\begin{tabular}{|c|c|c|c|}
\hline Entry & Catalyst $^{a}$ & Conditions & Yield $^{c}(\%)$ \\
\hline 1 & $\mathrm{Zn}\left(\mathrm{ClO}_{4}\right)_{2}$ & $80{ }^{\circ} \mathrm{C}, 12 \mathrm{~h}$ & Trace \\
\hline 2 & PTSA & $80^{\circ} \mathrm{C}, 12 \mathrm{~h}$ & - \\
\hline 3 & $\mathrm{AgSbF}_{6}$ & $60{ }^{\circ} \mathrm{C}, 8 \mathrm{~h}$ & - \\
\hline 4 & $\mathrm{AuCl}_{3}$ & $60{ }^{\circ} \mathrm{C}, 8 \mathrm{~h}$ & - \\
\hline 5 & $\left(\mathrm{PPh}_{3}\right) \mathrm{AuCl}$ & $60{ }^{\circ} \mathrm{C}, 8 \mathrm{~h}$ & - \\
\hline 6 & $\left(\mathrm{PPh}_{3}\right) \mathrm{AuCl} / \mathrm{AgSbF}_{6}$ & $60{ }^{\circ} \mathrm{C}, 6 \mathrm{~h}$ & 58 \\
\hline 7 & $\mathrm{AuCl}_{3} / \mathrm{AgSbF}_{6}$ & $60^{\circ} \mathrm{C}, 8 \mathrm{~h}$ & - \\
\hline 8 & $\mathrm{AuCl}_{3} / \mathrm{Zn}\left(\mathrm{ClO}_{4}\right)_{2}$ & $60{ }^{\circ} \mathrm{C}, 5 \mathrm{~h}$ & - \\
\hline 9 & $\left(\mathrm{PPh}_{3}\right) \mathrm{AuCl} / \mathrm{Zn}\left(\mathrm{ClO}_{4}\right)_{2}$ & $\mathrm{rt}, 12 \mathrm{~h}$ & 40 \\
\hline 10 & $\left(\mathrm{PPh}_{3}\right) \mathrm{AuCl} / \mathrm{Zn}\left(\mathrm{ClO}_{4}\right)_{2}$ & $60^{\circ} \mathrm{C}, 5 \mathrm{~h}$ & $65,70^{b}$ \\
\hline 11 & $\left(\mathrm{PPh}_{3}\right) \mathrm{AuCl} / \mathrm{Zn}\left(\mathrm{ClO}_{4}\right)_{2}$ & $90{ }^{\circ} \mathrm{C}, 3 \mathrm{~h}$ & 68 \\
\hline 12 & $\left(\mathrm{PPh}_{3}\right) \mathrm{AuCl} / \mathrm{Zn}(\mathrm{OTf})_{2}$ & $60{ }^{\circ} \mathrm{C}, 5 \mathrm{~h}$ & 63 \\
\hline 13 & $\left(\mathrm{PPh}_{3}\right) \mathrm{AuCl} / \mathrm{AgClO}{ }_{4}$ & $80^{\circ} \mathrm{C}, 8 \mathrm{~h}$ & $61^{d}$ \\
\hline
\end{tabular}

${ }^{a} 10 \mathrm{~mol} \%$ of each species in DCE. ${ }^{b} 15 \mathrm{~mol} \%$ of each species in DCE. ${ }^{c}$ Total yield $(\%)$ of $\mathbf{6 a a}$ and $7 \mathbf{a a}$ after column chromatography. ${ }^{d}$ A pre-formed cationic gold(I) catalyst is used. 
were observed at higher temperatures (entry 1$){ }^{13}$ To rule out the possible involvement of the conjugate Brønsted acid in alkyne activation, the reaction of $\mathbf{4 a}$ was performed in the presence of a catalytic amount of PTSA, in which no cyclization products were obtained (entry 2). Single metals such as $\mathrm{Ag}(\mathrm{I}), \mathrm{Au}(\mathrm{I})$, and $\mathrm{Au}(\mathrm{III})$ did not work as well (entries 3-5). As was planned beforehand, a combination of $\mathrm{Zn}(\mathrm{II})$ and $\mathrm{Au}(\mathrm{I})$ or $\mathrm{Au}(\mathrm{III})$ was feasible to catalyze this conversion. Unfortunately, $\mathrm{Au}$ (III) together with $\mathrm{Zn}$ (II) or $\mathrm{Ag}$ (I) did not induce the reaction sought (entries 7 and 8). However, the presence of $\mathrm{Au}(\mathrm{I})$, instead of $\mathrm{Au}(\mathrm{III})$, together with $\mathrm{Zn}$ (II), showed the formation of two products (6aa, 7aa) $(40 \%)$ at room temperature (entry 9). An increase in the reaction temperature was necessary to improve the conversion of the starting material $\left(5\right.$ hours, $60{ }^{\circ} \mathrm{C}, 65 \%$ ) (entry 10). At higher temperatures, however, other unidentified side products were observed.

The outcome of this experiment unambiguously demonstrated that the gold-based catalysis was uniquely responsible for the alkyne activation. Control reactions clearly indicate that the cationic $\mathrm{Au}(\mathrm{I})$ species is required for the reaction to proceed. In the absence of either $\mathrm{Zn}$ (II) or $\mathrm{Au}(\mathrm{I})$, no cyclization products were obtained at all. By far the best catalyst system was a combination of $\mathrm{Ph}_{3} \mathrm{PAuCl}(10 \mathrm{~mol} \%)$ and $\mathrm{Zn}$ (II) (10 mol\%) carried out in DCE (1,2-dichloroethane) at $60{ }^{\circ} \mathrm{C}$ in order to efficiently afford the pyrroles 6 and 7 . The reaction can be carried out in various solvents, such as DCM, DCE, toluene, acetonitrile, and ethanol, which gave similar results. Practical reasons made DCE the solvent of choice. Zinc perchlorate and zinc triflate salts were used as the $\mathrm{Zn}$ (II) source, which showed similar effects on the reaction yields and reaction time (entries 10 and 12).

The product distribution was carefully investigated (Table 2). The reaction of 4-yne-nitrile (4) with various amines ended up being regioselective, in turn giving pyrrole $\mathbf{6}$ as the major and pyrrole 7 as the minor product. The ratio of pyrrole 6 to 7 increases when carried out with the more nucleophilic in character aliphatic amines (benzylamine) (entry 7), which runs up (6/1), whereas the ratio decreases when carried out with comparably less nucleophilic aromatic amines (aniline, 3/2) (entries 1 and 13).

Except for the products carried out with 1-phenylethyl amine (entries 8 and 18), we were pleased that all of the regioisomeric pyrroles could be separated by column chromatography. The value of the product ratio was determined according to the isolated product yields. However, for inseparable isomers, this ratio was determined by ${ }^{1} \mathrm{H}-\mathrm{NMR}$.

With optimized reaction conditions in hand, two possible 2-aminopyrroles (6 and 7) were formed. This reaction works for a range of different amines. A variety of amines, such as aliphatic or aromatic amines, except for electron poor anilines (entries 4 and 16), reacted smoothly to afford the desired products. Starting yne-nitriles, possessing both internal and terminal alkynes, were employed for this cyclization (entries 10-12). For terminal alkynes, the reaction proceeded through an exo-dig cyclization in order to afford the corresponding five membered rings (pyrrole). For the methyl substituted internal alkyne (4d), however, the cyclization gave a six membered ring (compound 8) through a possible endo-dig cyclization (entry 11). Despite our great effort, the cyclization did not tolerate the internal alkynes substituted with both aryl and TMS groups (entries 10 and 12). In the case of TMS
Table 2 Scope of the reaction

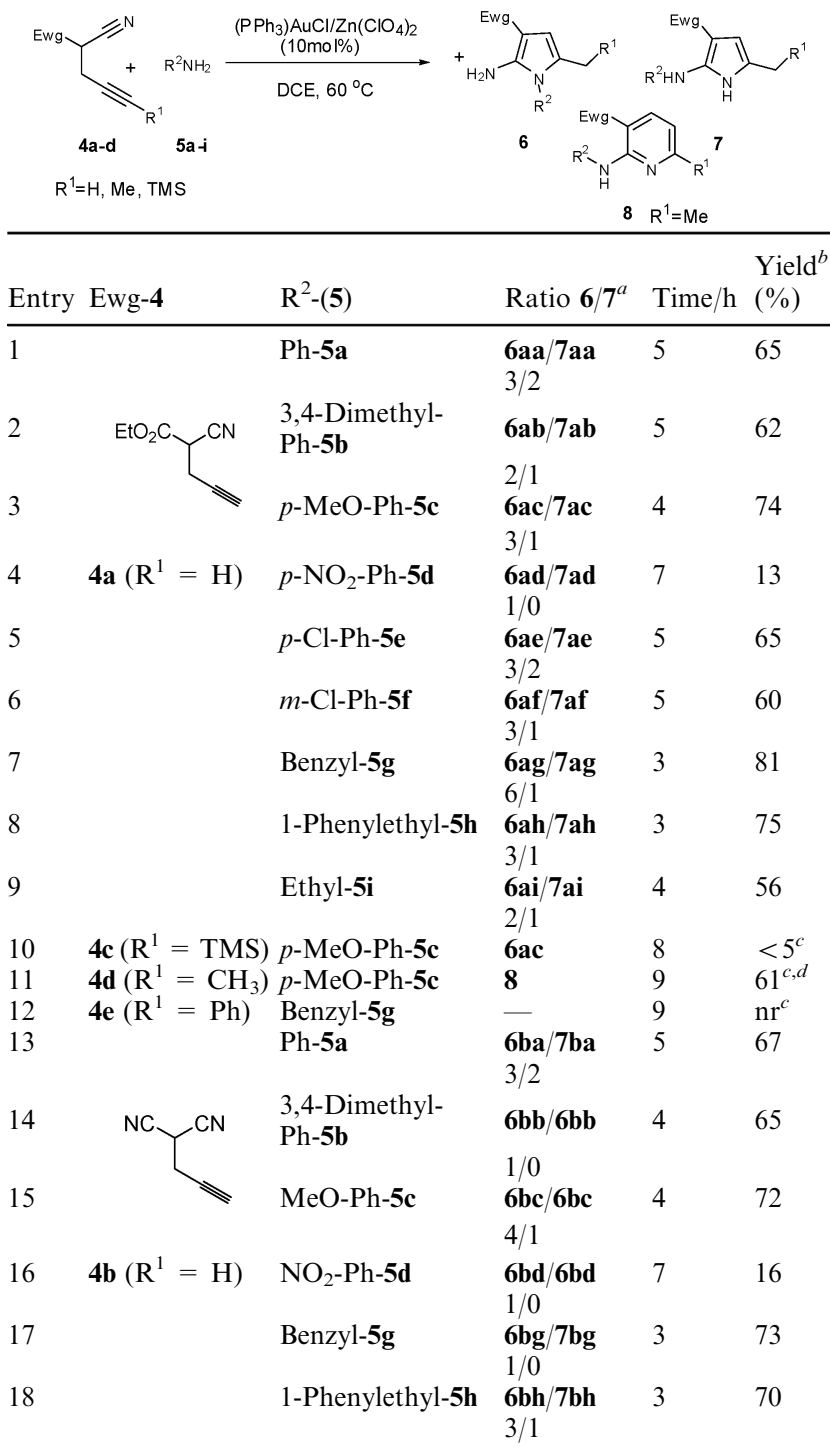

${ }^{a}$ Average ratio of at least two experiments. ${ }^{b}$ Total yield of compounds 6 and 7. ${ }^{c}$ Reaction carried out at $90{ }^{\circ} \mathrm{C} .{ }^{d}$ Yield of compound 8.

substitution, the only product that was isolated was a trace amount of pyrrole 6ac after in situ desilylation (entry 10).

The loading of both catalysts from 10 to $15 \mathrm{~mol} \%$ slightly $(5 \%)$ increased the reaction yield. However, higher amounts had no dramatic effect on the reaction yields. The $\mathrm{Ph}_{3} \mathrm{PAuCl} /$ $\mathrm{Ag}(\mathrm{I})$ catalyst system was also proven to catalyze this reaction (entry 6). In this system, $\operatorname{Ag}(\mathrm{I})$ may act in the same way as $\mathrm{Zn}$ (II). However, this combination was less effective than the $\mathrm{Ph}_{3} \mathrm{PAuCl} / \mathrm{Zn}$ (II) catalyst system. The additional parallel experiments were carried out with $\mathrm{AgSbF}_{6}$ and $\mathrm{Zn}\left(\mathrm{ClO}_{4}\right)_{2}$ under the standard conditions described above, in which the yields with $\mathrm{Zn}\left(\mathrm{ClO}_{4}\right)_{2}$ were in all cases higher (56-81\%) than with $\mathrm{AgSbF}_{6}(41-58 \%$ ) (Table S3, see ESI $\dagger$ ).

A plausible mechanism for the $\mathrm{Au}(\mathrm{I}) / \mathrm{Zn}$ (II)-catalyzed cyclization is shown in Scheme 3. First, $\mathrm{Zn}$ (II) enhances the electrophilicity of the nitrile, which allows the attack of the amine (5) at the nitrile to give the intermediate I. It seems to be that $\mathrm{Zn}$ (II) has a dual effect of nitrile activation and chloride ligand abstraction 


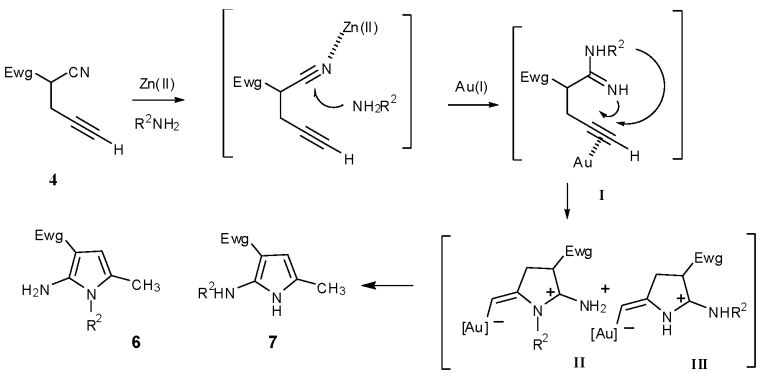

Scheme 3 Plausible mechanism for pyrrole formation.

from $\mathrm{Ph}_{3} \mathrm{PAuCl}$. This is also supported by the parallel experiments carried out with $\mathrm{AgSbF}_{6}$ and $\mathrm{Zn}\left(\mathrm{ClO}_{4}\right)_{2}$, in which the yields with $\mathrm{Zn}\left(\mathrm{ClO}_{4}\right)_{2}$ were in all cases higher than with $\mathrm{AgSbF}_{6}$, and where the attack of both nitrogen pronucleophiles of intermediate I at the Au(I) activated alkyne would allow for the intermediates II and III. Further arrangement leads to the formation of 2-aminopyrroles 6 and 7 (Scheme 3).

We succeeded in developing an $\mathrm{Au}(\mathrm{I}) / \mathrm{Zn}$ (II) catalyzed tandem cyclization of 4-pentyne-nitriles with various amines that provided an efficient and general route to pyrroles with a wide range of substituents. To our knowledge, this is the only report in which the cationic $\mathrm{Au}$ (I) species has been combined with $\mathrm{Zn}$ (II) salts, which cooperatively catalyze the hydroamination/ annulation reaction of 4-yne-nitriles. Further studies on the mechanism, elucidating the product distribution of this reaction, and extending the scope of synthetic utility are currently in progress in our laboratory.

We gratefully acknowledge the Scientific and Technological Research Council of Turkey (TÜBITAK), the Turkish Academy of Sciences (TÜBA), and the Middle East Technical University (METU).

\section{Notes and references}

1 For recent reviews on gold catalyzed reactions, see: (a) Y. Yamamoto, I. D. Gridnev, N. T. Patil and T. Jin, Chem. Commun., 2009, 5075-5087; (b) R. Skouta and C.-J. Li, Tetrahedron, 2008, 64, 4917-4938; (c) Z. Li, C. Brouwer and C. He, Chem. Rev., 2008, 108, 3239-3265; (d) A. Arcadi, Chem. Rev., 2008, 108, 3266-3325; (e) E. Jiménez-Núnez and A. M. Echavarren, Chem. Rev., 2008, 108, 3326-3350; (f) D. J. Gorin, B. D. Sherry and F. D. Toste, Chem. Rev., 2008, 108, 3351-3378; $(g)$ N. T. Patil and Y. Yamamoto, Chem. Rev., 2008, 108, 3395-3442; (h) H. C. Shen, Tetrahedron, 2008, 64, 3885-3903; (i) N. Krause, V. Belting, C. Deutsch, J. Erdsack, H. T. Fan, B. Gockel, A. Hoffmann-Roder, N. Morita and F. Volz, Pure Appl. Chem., 2008, 80, 1063-1069; (j) A. Fürstner and P. W. Davies, Angew. Chem., Int. Ed., 2007, 46, 3410-3449; (k) A. S. K. Hashmi, Chem. Rev., 2007, 107, 3180-3211; (l) D. J. Gorin and F. D. Toste, Nature, 2007, 446, 395-403; (m) N. Marion and S. P. Nolan, Chem. Soc. Rev., 2008, 37, 1776-1782; (n) A. S. K. Hashmi, Angew. Chem., 2005, 117, 7150-7154 (Angew. Chem., Int. Ed., 2005, 44, 6990); (o) A. S. K. Hashmi and G. J. Hutchings, Angew. Chem., 2006, 118, 8064-8105 (Angew. Chem., Int. Ed., 2006, 45, 7896); (p) A. Hoffmann-Röder and N. Krause, Org. Biomol. Chem., 2005, 3, 387-391; (q) A. S. K. Hashmi, Gold Bull., 2004, 37, 51-65; (r) A. S. K. Hashmi, Gold Bull., 2003, 36, 3-9.

2 For selected gold-catalyzed tandem reactions with external nucleophiles, see: (a) J. Meng, Y.-L. Zhao, C.-Q. Ren, Y. Li, Z. Li and Q. Liu, Chem.-Eur. J., 2009, 15, 1830-1834; (b) V. Belting and N. Krause, Org. Biomol. Chem., 2009, 7, 1221-1225; (c) L. Leseurre, P. Y. Toullec, J.-P. Genet and V. Michelet, Org. Lett., 2007, 9, 4049-4052; (d) A. K. Buzas, F. M. Istrate and F. Gagosz, Angew. Chem., Int. Ed., 2007, 46, 1141-1144; (e) T. Yang, L. Campbell and D. J. Dixon, J. Am. Chem. Soc.,
2007, 129, 12070-12071; (f) A. K. Buzas, F. M. Istrate and F. Gagosz, Angew. Chem., Int. Ed., 2007, 46, 1141; (g) C. H. M. Amijs, C. Ferrer and A. M. Echavarren, Chem. Commun., 2007, 698-700; (h) L.-Z. Dai, M.-J. Qi, Y.-L. Shi, X.-G. Liu and M. Shi, Org. Lett., 2007, 9, 3191-3194; (i) J. Zhang and H.-G. Schmalz, Angew. Chem., Int. Ed., 2006, 45, 6704-6707; (j) A. S. K. Hashmi, M. Rudolph, S. Schymura, J. Visus and W. Frey, Eur. J. Org. Chem., 2006, 4905-4909; (k) V. Belting and N. Krause, Org. Lett., 2006, 8, 4489-4492; (l) Y. Horino, M. R. Luzung and F. D. Toste, J. Am. Chem. Soc., 2006, 128, 11364-11365; (m) S. Park and D. Lee, J. Am. Chem. Soc., 2006, 128, 10664-10665.

3 For a microreview on hydroamination of multiple systems, see: A. Ross, R. A. Widenhoefer and X. Han, Eur. J. Org. Chem., 2006, 4555-4563.

4 For selected gold-catalyzed hydroamination reactions, see: (a) A. S. K. Hashmi, M. Buhrle, M. Wolfle, M. Rudolph, M. Wieteck, F. Rominger and W. Frey, Chem.-Eur. J., 2010, 16, 9846-9854; (b) Y. Zhang, J. P. Donahue and C.-J. Li, Org. Lett., 2007, 9, 627-630; (c) J.-E. Kang, H.-B. Kim, J.-W. Lee and S. Shin, Org. Lett., 2006, 8, 3537-3540; (d) I. Nakamura, U. Yamagishi, D. Song, S. Konta and Y. Yamamoto, Angew. Chem., Int. Ed., 2007, 46, 2284-2287; (e) I. V. Seregin, A. W. Schammel and V. Gevorgyan, Org. Lett., 2007, 9, 3433-3436; ( $f$ ) D. J. Gorin, N. R. Davis and F. D. Toste, J. Am. Chem. Soc., 2005, 127, 11260-11261; (g) N. Morita and N. Krause, Org. Lett., 2004, 6 , 4121-4123; (h) Z. Zhang, C. F. Bender and R. A. Widenhoefer, Org. Lett., 2007, 9, 2887-2889; (i) P. H. Lee, H. Kim, K. Lee, M. Kim, K. Noh, H. Kim and D. Seomoon, Angew. Chem., Int. Ed., 2005, 44, 1840-1843; (j) R. L. LaLonde, B. D. Sherry, E. J. Kang and F. D. Toste, J. Am. Chem. Soc., 2007, 129, 2452-2453; (k) C. F. Bender and R. A. Widenhoefer, Org. Lett., 2006, 8, 5303-5308; (l) C. F. Bender and R. A. Widenhoefer, Chem. Commun., 2006, 4143-4144; (m) X.-Y. Liu, C.-H. Li and C.-M. Che, Org. Lett., 2006, 8, 2707-2710; (n) C.-Y. Zhou and C.-M. Che, J. Am. Chem. Soc., 2007, 129, 5828-5829; (o) T. Enomoto, A.-L. Girard, Y. Yasui and Y. Takemoto, J. Org. Chem., 2009, 74, 9158; (p) X.-Y. Liu, P. Ding, J.-S. Huang and J.-M. Che, Org. Lett., 2007, 9, 2645-2648.

5 For transition metal catalyzed pyrrole synthesis, see: (a) S. Kamijo, C. Kanazawa and Y. Yamamoto, J. Am. Chem. Soc., 2005, 127, 9260-9266; (b) A. I. Siriwardana, K. K. A. D. S. Kathriarachchi, I. Nakamura, I. D. Gridnev and Y. Yamamoto, J. Am. Chem. Soc., 2004, 126, 13898-13899; (c) X. Yuan, X. Xu, X. Zhou, J. Yuan, L. Mai and Y. Li, J. Org. Chem., 2007, 72, 1510-1513; (d) B. Gabriele, G. Salerno and A. Fazio, J. Org. Chem., 2003, 68, 7853-7861; (e) D. U. Braun, K. Zietler and T. J. J. Müller, Org. Lett., 2001, 3, 3297-3300; (f) H. Shiraishi, T. Nishitani, S. Sakaguchi and Y. Ishii, J. Org. Chem., 1998, 63, 6234-6238.

6 For gold-catalyzed pyrrole synthesis, see: (a) Y. Lu, X. Fu, H. Chen, X. Du, X. Ji and Y. Liu, Adv. Synth. Catal., 2009, 351, 129-134; (b) X. Shu, X. Liu, H. Xiao, K. Ji, L. Guo and Y. Liang, Adv. Synth. Catal., 2008, 350, 243; (c) N. Martin and P. W. Davies, Org. Lett., 2009, 11, 2293-2296; (d) J. T. Binder and S. T. Kirsch, Org. Lett., 2006, 8, 2151-2153; (e) C. A. Witham, P. Mauleon, N. D. Shapiro, B. D. Sherry and F. D. Toste, J. Am. Chem. Soc., 2007, 129, 5838-5839.

7 (a) A. S. Demir, M. Emrullahoğlu and G. Ardahan, Tetrahedron, 2007, 63, 461-468; (b) A. S. Demir and M. Emrullahoğlu, Tetrahedron, 2006, 62, 1452-1458; (c) A. S. Demir and M. Emrullahoğlu, Tetrahedron, 2005, 61, 10482-10489.

8 (a) A. Trani and E. Bellasio, Farmaco, Ed. Sci., 1983, 38, 940-949; (b) C. Yaroslavsky, P. Bracha and R. Glaser, J. Heterocycl. Chem., 1989, 26, 1649-1654.

9 (a) M. T. Cocco, C. Congiu, A. Maccioni, M. L. Schivo, A. De Logu and G. Palmieri, Farmaco, Ed. Sci., 1988, 43, 951-960; (b) O. M. Z. Howard, J. J. Oppenheim, M. G. Melinda, J. M. Covey and J. Bigelow, J. Med. Chem., 1998, 41, 2184-2193.

10 S. H. Krawezyk, M. R. Nassiri, L. S. Kucera, E. R. Kern and R. G. Ptak, J. Med. Chem., 1995, 38, 4106-4114.

11 S. M. Bennett, N. Ba Nghe and K. K. Ogilvie, J. Med. Chem., 1990, 33, 2162-2173.

12 D. P. Curran and C. M. Seong, Tetrahedron, 1992, 48, 2175-2190; A. Goeta, M. M. Salter and H. Shah, Tetrahedron, 2006, 62, $3582-3599$.

13 K. Okuma, J. Seto, K. Sakaguchi, S. Ozaki, N. Nagahora and K. Shioji, Tetrahedron Lett., 2009, 50, 2943-2945. 